\title{
THE DIFFERENTIAL TOXICITY OF AMMONIUM SALTS
}

\author{
BY KENNETH S WARREN \\ (From the United States Department of Health, Education, and Welfare, Public Health Service, \\ National Institutes of Health, National Institute of Allergy and Infectious Diseases, 1
}

Bethesda, Md.)

(Submitted for publication October 15, 1957 ; accepted November 25, 1957)

The relationship between liver disease and ammonia toxicity has been known since the discovery of meat intoxication in Eck fistula dogs (1-4). The similarity between this syndrome and clinical hepatic coma stimulated the study of ammonia toxicity in humans. This proceeded from oral administration (5-10) to intravenous infusion $(11,12)$ and finally to the development of an "ammonia tolerance test" $(13,14)$. Ammonia toxicity studies have been performed in animals by the intravenous (15-24), oral, subcutaneous, and intraperitoneal routes (25-29).

Many different ammonium compounds were used in the above studies with the tacit assumption that their toxicities were similar. In order to test that assumption, intravenous LD50's were determined in mice under controlled conditions.

\section{MATERIALS AND METHODS}

Intravenous LD50's were determined in young Swiss albino mice, weighing 18 to $22 \mathrm{Gm}$. (average, $19.7 \mathrm{Gm}$.). One ml. of isotonic saline containing the ammonium compounds (reagent grade) in varying concentrations was injected into a tail vein during an average time of 1.9 seconds. The lethal effect was determined in 10 animals for each of three to five concentration levels. The mice were observed continually until all signs of acute toxicity disappeared and then were examined during the course of several days for the appearance of any latent toxicity.

Blood pH was determined with a Beckman Model GS meter, equipped with a $290-80$ blood electrode, on heart blood obtained from live, unanesthetized animals. The effect of each ammonium salt on the blood $\mathrm{pH}$ was measured within one minute of its intravenous administration.

The LD50's and approximate 95 per cent confidence limits were obtained by the Carver method (30).

\section{RESULTS}

When the intravenous LD50's of ammonium chloride, citrate, acetate, bicarbonate, carbonate, and hydroxide were determined, differences in

\footnotetext{
1 Laboratory of Tropical Diseases.
}

their toxicities were noted. On studying the relationship of the LD50's to the pH's of the compounds in isotonic saline and their effect on the blood $\mathrm{pH}$ (normal, $7.46 \pm 0.02$ ), it was observed that the toxicity of the compounds increased with a rise in $\mathrm{pH}$, as shown in Figure 1. A notable exception was ammonium citrate which, although it had the lowest $\mathrm{pH}$, displayed the highest toxicity. The data pertaining to this seemingly aberrant effect are not represented in Figure 1 but will be presented below, as the toxicity of ammonium citrate does not appear to be due to the ammonium moiety.

When the ammonium salts, with the exception of citrate, were administered in a single rapid intravenous dose (between the minimal and maximal lethal doses), a reaction began in 2 to $5 \mathrm{sec}-$ onds, characterized by hyperventilation and clonic convusions. This was followed by either a fatal tonic extensor convulsion or the gradual onset of coma over the course of three to five minutes. The mice remained in a comatose state for approximately 30 to 45 minutes, showing no response to touch or light, but moving convulsively to sound stimuli. During this time a tonic convulsion and death, without cardiac arrest, could occur at any time, but those mice which survived made a rapid and complete recovery.

There was no discernible effect from the injection of 1 or even $2 \mathrm{ml}$. of isotonic saline. The injection of the maximum lethal dose of ammonium chloride over increasingly prolonged time periods of one-half, one, two, four, and six minutes revealed only a slight diminution of toxicity at four to six minutes. Since the toxicity of the ammonium salts appeared to vary with the $\mathrm{pH}$, the effects of $\mathrm{Na}_{2} \mathrm{CO}_{3} / \mathrm{NaHCO}_{3}$ and $\mathrm{Na}_{2} \mathrm{HPO}_{4} /$ $\mathrm{NaH}_{2} \mathrm{PO}_{4}$ buffers with concentrations and $\mathrm{pH}$ 's approximating the maximum lethal doses of ammonium chloride and ammonium hydroxide were studied. There was no evidence of toxicity. In 


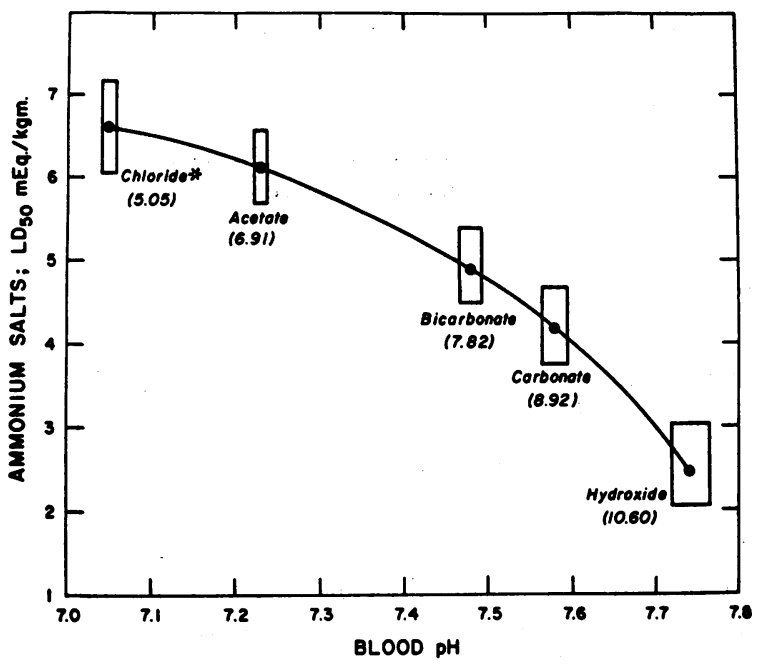

Fig. 1. LD50's of Ammonium Salts and the Resultant $\mathrm{PH}$ of Blood One Minute After Injection

The rectangle surrounding the points determined denotes, on the ordinate, the approximate 95 per cent confidence limits, and on the abscissa, the standard error of the mean $\mathrm{pH}$-average for 10 animals.

$* \mathrm{pH}$ of the solution administered.

order to determine the effect of the anionic component of the ammonium salts, sodium salts of each compound were injected in a concentration equivalent to the maximum lethal dose, and again no toxicity was noted. Attempts to achieve a prior alkalosis, either metabolic or respiratory, were negated by the overpowering effect of the intravenously administered ammonium compounds.

Since the physical state in which ammonia exists might influence its toxicity, it was of interest to calculate the relative amounts of ammonium ion and ammonia gas at the pH's of the LD50 concentrations. In order to do this the following for-

TABLE I

The effect of blood $p H$ on the ratio of ammonia gas to ammonium ion

\begin{tabular}{|c|c|c|c|c|c|}
\hline$\underset{\text { salt }}{\text { Ammonium }}$ & $\begin{array}{c}\text { LD } \\
\text { concen- } \\
\text { tration } \\
m E q . / L .^{*}\end{array}$ & $\underset{\mathrm{pH}}{\text { Blood }}$ & $\underset{m E q . / L .}{\mathrm{NH}_{2}}$ & $\underset{m E q . / L .}{\mathrm{NH}_{4}^{+}}$ & $\underset{\mathrm{NH}_{\mathbf{2}} / \mathrm{NH}_{4}+}{\text { Ratio }}$ \\
\hline $\begin{array}{l}\text { Chloride } \\
\text { Acetate } \\
\text { Bicarbonate } \\
\text { Carbonate } \\
\text { Hydroxide }\end{array}$ & $\begin{array}{r}135.0 \\
124.6 \\
100.9 \\
89.3 \\
50.5\end{array}$ & $\begin{array}{l}7.05 \\
7.23 \\
7.48 \\
7.58 \\
7.74\end{array}$ & $\begin{array}{l}0.84 \\
1.16 \\
1.67 \\
1.85 \\
1.50\end{array}$ & $\begin{array}{r}134.16 \\
123.44 \\
99.23 \\
87.45 \\
49.00\end{array}$ & $\begin{array}{l}0.0063 \\
0.0094 \\
0.0168 \\
0.0212 \\
0.0306\end{array}$ \\
\hline
\end{tabular}

* One ml. administered intravenously to each animal.
TABLE II

The toxicity of ammonium citrate

\begin{tabular}{lcc}
\hline \multicolumn{1}{c}{$\begin{array}{c}\text { Solution } \\
\text { administered }\end{array}$} & $\begin{array}{c}\mathrm{LD}_{\text {so concentration }} \\
\text { of citrate salts } \\
\mathrm{mE} \text { E./Kg. }\end{array}$ & $\begin{array}{c}\text { Solution } \\
\mathrm{pH}\end{array}$ \\
\hline Ammonium citrate & $1.58(1.52-1.63)^{*}$ & 4.86 \\
$\begin{array}{l}\text { Ammonium citrate }+ \\
\text { calcium gluconate }\end{array}$ & $8.40(8.03-8.79)$ & 4.63 \\
Sodium citrate & $1.94(1.86-2.02)$ & $4.90 \dagger$
\end{tabular}

* Approximate 95 per cent confidence limits. $\dagger \mathrm{pH}$ adjusted to 4.90 with $\mathrm{HCl}$.

mula was derived from the mass action law:

$$
\frac{\mathrm{X}}{(\mathrm{Y}-\mathrm{X})\left(\mathrm{H}^{+}\right)}=1.8 \times 10^{\circ},{ }^{2}
$$

where $\mathrm{X}$ equals $\mathrm{NH}_{4}{ }^{+}$and $\mathrm{Y}$ equals total ammonia. The data calculated from the above formula, summarized in Table I, reveal that as the blood $\mathrm{pH}$ rises, the amount of ammonia gas relative to ammonium ion increases markedly.

When ammonium citrate was administered, toxicity appeared to develop in a manner somewhat different from that of the other ammonium compounds. The animals immediately began to leap about exhibiting tetanic movements of all limbs, followed by the sudden onset of apnea and death, with the heart still beating. They never developed the clonic-tonic convulsions typical of ammonia toxicity, and either died in a few minutes or recovered rapidly, with no subsequent development of coma. In order to test whether this effect was due to the citrate moiety and the induction of hypocalcemia, enough calcium in the form of calcium gluconate was added to ammonium citrate, on an equivalent weight basis to bind the citrate completely. As is shown in Table II, the toxicity was reduced below that of ammonium chloride. The toxicity of sodium citrate at a similar $\mathrm{pH}$ was approximately the same as that of ammonium citrate. Calcium gluconate had no effect on ammonium chloride toxicity.

\section{DISCUSSION}

The material presented in Table I, illustrating an increased ratio of ammonia gas to ammonium ion with a rise in blood $\mathrm{pH}$, may explain the differential toxicity of the ammonium salts studied.

2 This figure was derived from the dissociation constant of $\mathrm{NH}_{4} \mathrm{OH}$. 
Preliminary data gathered in this laboratory (31) revealed that the greater part of the ammonia administered in a single injection passed from the blood in less than three minutes. In spite of this fall in ammonia level, our mice did not become comatose for 3 to 4 minutes and they remained in coma for at least 30 minutes. This may indicate a rapid and early passage of ammonia into the brain. Therefore, the effect of $\mathrm{pH}$ on the bloodbrain-barrier may be related to either the greater permeability of free than ionized ammonia, or to an effect of $\mathrm{pH}$ directly on the barrier itself.

The $\mathrm{pH}$ of the medium in which ammonium salts are dissolved has been shown to influence the ability of ammonia to cross cell boundaries in both red blood cells (32) and other tissues (33). This appears to be due to the amount of ammonia gas versus ammonium ion in that the unionized ammonia has a much greater ability to penetrate cells. Jacobs and Stewart (33) have shown that the ammonium salts of weak acids, such as acetate, bicarbonate, and benzoate, penetrate all cells with great ease, while ammonium salts of strong acids, chloride, nitrate, and sulfate apparently do so no more readily than the corresponding potassium and sodium salts. The latter salts have been shown to cross the blood-brain-barrier at an extremely slow rate (34), requiring a much greater time to equilibrate with the brain than with other tissues. In all probability, ammonia gas can penetrate this barrier as rapidly as other gases, and as readily as it passes other tissue barriers.

A direct effect of $\mathrm{pH}$ changes on the blood-brainbarrier has been reported by Broman and Lind-
berg-Broman (35) who found that extreme changes in $\mathrm{pH}$ increase the permeability of the blood-brain-barrier to trypan blue. Fisher, Troast, Waterhouse, and Shannon (36) have shown that the amount of a given sulfa drug that crosses the barrier is dependent on the $\mathrm{pK}$ of the compound; the higher the $\mathrm{pK}$ the greater the passage. The question resolves itself, therefore, as to whether more ammonia crosses the barrier at high $\mathrm{pH}$ 's because of the increased ammonia gas to ammonium ion ratio, or whether there is a direct effect on the blood-brain-barrier itself, or both. Animal studies now in progress may provide an answer.

Other investigators have studied the toxicity of different ammonium salts. As early as 1893, Marfori (15) noted that ammonium carbonate was much more toxic than either ammonium lactate or tartrate during slow intravenous infusion into rabbits and dogs. Roberts, Thompson, Poppell, and Vanamee (23) have recently speculated that an elevation of blood $\mathrm{pH}$ could enhance the toxicity of ammonia; nevertheless, several investigators have found no such relationship. Following the administration of ammonium compounds to dogs, Karr and Hendricks (20) felt that the effect of $\mathrm{pH}$ on ammonia within physiological limits was negligible, and although Iwahashi (29) noted differences in toxicity of the compounds in mice, he could find no consistent pattern. Eiseman, Fowler, White, and Clark (24) administered ammonium salts intravenously to dogs and concluded that there was no relationship between $\mathrm{pH}$ and ammonia toxicity. Since

TABLE III

Tabulation of the data of Eiseman and co-workers (24) on the infusion of ammonium compounds into dogs

\begin{tabular}{|c|c|c|c|c|c|c|c|}
\hline$\underset{\text { salt }}{\text { Ammonium }}$ & $\begin{array}{l}\text { Concentration and } \\
\text { rate of infusion }\end{array}$ & $\begin{array}{c}\text { Total } \\
\text { time } \\
\text { infused } \\
\text { hours }\end{array}$ & $\begin{array}{c}\text { Highest } \\
\text { blood } \\
\text { ammonia } \\
\text { level } \\
\text { Mg. NH,l } \\
\text { ml. }\end{array}$ & $\begin{array}{c}\text { Blood } \\
\text { ammonia } \\
\text { during } \\
\text { coma } \\
\text { g. } \mathrm{NH}_{3} / \\
\mathrm{ml} .\end{array}$ & $\begin{array}{c}\text { Total } \\
\text { NH } \\
\text { infused } \\
\text { Gm. }\end{array}$ & $\begin{array}{l}\text { Blood } \\
\text { pH at } \\
\text { coma }\end{array}$ & Remarks \\
\hline Chloride & $\begin{array}{l}5 \% \\
2 \mathrm{ml} . / \mathrm{min} .2 \mathrm{hrs} . \\
1 \mathrm{ml} . / \mathrm{min} .2 \mathrm{hrs} .\end{array}$ & 4 & 175 & 90 & 5.73 & 6.9 & Convulsion at $4 \mathrm{hrs}$. \\
\hline $\begin{array}{l}\text { Hydroxide } \\
\text { and } \mathrm{HCl}, \mathrm{pH} 8.8\end{array}$ & $\begin{array}{l}1 \% \\
1 \% \mathrm{ml} . / \mathrm{min} .\end{array}$ & 5 & 40 & 35 & 1.46 & 7.4 & \\
\hline Hydroxide & $\begin{array}{l}1 \% \\
1 \% \mathrm{ml} . / \mathrm{min} .\end{array}$ & 4.5 & 50 & 20 & 1.31 & 7.6 & \\
\hline Citrate & $\begin{array}{l}4 \% \\
2 \mathrm{ml} . / \mathrm{min} .\end{array}$ & 3 & 30 & 20 & 2.14 & 7.2 & $\begin{array}{l}\text { Convulsion, } 2 \mathrm{hrs} \text {; } \\
\text { tremors, } 40 \mathrm{~min} \text {. }\end{array}$ \\
\hline
\end{tabular}


their data are particularly pertinent to this discussion, they are summarized in Table III. The concentrations of the drugs administered, as well as the rates and times of infusion and the blood ammonia levels at onset of coma, were not uniform. The symptomatology evinced by the dog given ammonium citrate did differ from those given the other salts in that there were tremors at an early stage and a convulsion about midway in the course of the infusion. Their data not only suggest a relationship between blood $\mathrm{pH}$ and ammonia toxicity, but also reveal the excessive toxicity of ammonium citrate.

Since ammonium citrate is being used with increasing frequency in both animal and human studies $(12,14,24)$, it is important to note that in a single intravenous lethal dose in mice the citrate moiety is more toxic than the ammonium moiety. The mice die in tetany due to hypocalcemia rather than in a manner consistent with ammonia toxicity. Therefore, the use of ammonium citrate in human experimentation, particularly when administered via the intravenous route, might be contraindicated.

In relation to clinical hepatic coma and its therapy, Gyorgyi and Kleinschmidt (37) in 1927 found that dogs with Eck fistulas in meat intoxication were alkalotic. Vanamee, Poppell, Glicksman, Randall, and Roberts (38) showed, and it was confirmed by Robin, Whaley, Crump, and Travis (39), that the majority of patients in hepatic coma develop a respiratory alkalosis due to hyperventilation with blood pH's as high as 7.70. This alkalosis may effect significantly the toxicity of a given amount of ammonia in the blood and may be one of the factors accounting for the poor relationship between blood ammonia levels (arterial and venous) and clinical hepatic coma.

Gyorgyi and Kleinschmidt (37) noted further that the oral administration of hydrochloric acid brought about a rapid improvement even in severely intoxicated animals. The administration of acidifying agents or carbon dioxide to patients in hepatic coma may therefore prove to be beneficial.

\section{SUMMARY}

1. Intravenous LD50's of several ammonium salts were obtained in mice.
2. The ammonia toxicity of the chloride, acetate, bicarbonate, carbonate, and hydroxide salts increased in relation to their effect in raising blood $\mathrm{pH}$.

3. This change appeared to be related either to the effect of $\mathrm{pH}$ on the $\mathrm{NH}_{3} / \mathrm{NH}_{4}{ }^{+}$ratio and the ability of ammonia gas to cross the blood-brainbarrier, or to a direct effect of $\mathrm{pH}$ on the barrier.

4. The toxicity of ammonium citrate, under the above conditions, does not appear to be related to ammonium toxicity, but to hypocalcemic tetany induced by chelation of calcium by the citrate moiety.

5. Evidence was cited from the literature supporting these results obtained in mice by similar experiments in rabbits and dogs.

6. Therapeutic implications are discussed in the light of the recent findings that respiratory alkalosis is a frequent accompaniment of the hepatic coma syndrome.

\section{ACKNOWLEDGMENTS}

The author is indebted to Drs. Eugene C. Weinbach and Louis J. Olivier for their thoughtful criticism; Drs. William B. DeWitt and DeWitt S. Goodman for advice; and Mr. Nathan Mantel for assistance in the statistical analysis of the data.

\section{REFERENCES}

1. Nencki, M., Pawlow, J. P., and Zaleski, J. Uber den Ammoniakgehalt des Blutes und der Organe und die Harnstoffbildung bei den Säugethieren. Naunyn-Schmiedeberg's Arch. exp. Path. Pharmak. 1896, 37, 26.

2. Salaskin, S. Ueber das Ammoniak in physiologischer und pathologischer Hinsicht und die Rolle der Leber im Stoffwechsel stickstoffhaltiger Substanzen. Hoppe-Seylers Z. physiol. Chem. 1898, 25, 449.

3. Horodynski, W., Salaskin, S., and Zaleski, J. Ueber die Vertheilung des Ammoniaks im Blute und den Organen normaler und hungernder Hunde. HoppeSeylers Z. physiol. Chem. 1902, 35, 246.

4. Biedl, A., and Winterberg, H. Beiträge zur Lehre von der Ammoniakentgiftenden Function der Leber. Pflüg. Arch. ges. Physiol. 1901, 88, 140.

5. Van Caulaert, C., and Deviller, C. Ammoniémie expérimentale après ingestion de chlorure d'ammonium chez l'homme à l'état normal et pathologique. C. R. Soc. Biol. (Paris) 1932, 111, 50.

6. Van Caulaert, C., Deviller, C., and Halff, M. Le taux de l'ammoniémie dans certaines affections hépatiques. C. R. Soc. Biol. (Paris) 1932, 111, 735.

7. Van Caulaert, C., Deviller, C., and Hofstein, J. Epreuve de l'ammoniémie provoquée. Répartition 
de l'ammoniaque dan le sang et les humeurs. R. Soc. Biol. (Paris) 1932, 111, 737.

8. Van Caulaert, C., Deviller, C., and Halff, M. Troubles provoqués par l'ingestion de sels ammoniacaux chez l'homme atteint de cirrhose de Laennec. C. R. Soc. Biol. (Paris) 1932, 111, 739.

9. Fuld, H. Uber die diagnostische Verwertbarkeit von Ammoniakbestimmungen im Blut. Klin. Wschr. 1933, 12, 1364.

10. Kirk, E. Amino acid and ammonia metabolism in liver diseases. Acta med. scand. 1936, Suppl. 77.

11. Seegmiller, J. E., Schwartz, R., and Davidson, C. S. The plasma "ammonia" and glutamine content in patients with hepatic coma. J. clin. Invest. 1954, 33, 984.

12. Fahey, J. L., Nathans, D., and Rairigh, D. Effect of L-arginine on elevated blood ammonia levels in man. Amer. J. Med. 1957, 23, 860.

13. White, L. P., Phear, E. A., Summerskill, W. H. J., and Sherlock, S. Ammonium tolerance in liver disease: Observations based on catheterization of the hepatic veins. J. clin. Invest. 1955, 34, 158.

14. Eiseman, B., Lindeman, G. M., and Clark, G. M. Clinical evaluation of the ammonium citrate tolerance test for determining the patency of a portacaval shunt. J. Lab. clin. Med. 1956, 48, 579.

15. Marfori, P. Uber die Ammoniakmengen, welche der Organismus in Harnstoff umzuwandeln vermag. Naunyn-Schmiedeberg's Arch. exp. Path. Pharmak. 1894, 33, 71.

16. Meneguzzi, R. Ricerche farmacologiche sul cloruro d'ammonio. Arch. Farmacol. sper. 1913, 14, 411.

17. Jacobson, $C$. The concentration of ammonia in the blood of dogs and cats necessary to produce ammonia tetany. Amer. J. Physiol. 1910, 26, 407.

18. Matthews, S. A. Ammonia, a causative factor in meat poisoning in Eck-fistula dogs. Amer. J. Physiol. 1922, 59, 459.

19. Tauber, H., and Kleiner, I. S. Studies on crystalline urease. III. The toxicity of crystalline urease. J. biol. Chem. 1931, 92, 177.

20. Karr, N. W., and Hendricks, E. L. The toxicity of intravenous ammonium compounds. Amer. J. med. Sci. 1949, 218, 302.

21. Benitez, D., Pscheidt, G. R., and Stone, W. E. Formation of ammonium ion in the cerebrum in fluoroacetate poisoning. Amer. J. Physiol. 1954, 176, 488.

22. DeRiemer, R. H., Hine, D. E., and Harper, H. A. An evaluation of ammonia intoxication in normal dogs and in dogs having a portacaval anastomosis. Surg. Forum 1954, 5, 205.

23. Roberts, K. E., Thompson, R. F. G., III, Poppell, J. W., and Vanamee, P. Respiratory alkalosis accompanying ammonium toxicity. J. appl. Physiol. 1956, 9, 367.
24. Eiseman, B., Fowler, W. G., White, P. J., and Clark, G. M. The role of ammonia in the production of hepatic coma. Surg. Forum 1955, 6, 369.

25. Spector, W. S. Handbook of Toxicology. Philadelphia, Saunders, 1956, vol. 1, p. 22.

26. Richter, D., and Dawson, R. M. C. The ammonia and glutamine content of the brain. J. biol. Chem. 1948, 176, 1199.

27. Tigerman, H., and MacVicar, R. Glutamine, glutamic acid, ammonia administration and tissue glutamine. J. biol. Chem. 1951, 189, 793.

28. Torda, C. Ammonium ion content and electrical activity of the brain during the preconvulsive and convulsive phases induced by various convulsants. J. Pharmacol. exp. Ther. 1953, 107, 197.

29. Iwahashi, N. On convulsion caused by ammonia. Kumamoto. med. J. 1956, 9, 97.

30. Cornfield, J., and Mantel, N. Some new aspects of the application of maximum likelihood to the calculation of the dosage-response curve. J. Amer. Stat. Ass. 1950, 45, 181.

31. Warren, K. S, and Nathan, D. G. Unpublished data.

32. Jacobs, M. H., and Parpart, A. K. Osmotic properties of the erythrocyte. $X$. On the permeability of the erythrocyte to ammonia and the ammonium ion. J. cell. comp. Physiol. 1938, 11, 175.

33. Jacobs, M. H., and Stewart, D. R. The distribution of penetrating ammonium salts between cells and their surroundings. J. cell. comp. Physiol. 1936, 7, 351.

34. Bakay, L. The Blood-Brain-Barrier, With Special Regard To The Use Of Radioactive Isotopes. Springfield, Charles C Thomas, 1956.

35. Broman, T., and Lindberg-Broman, A. M. An experimental study of disorders in the permeability of the cerebral vessels (the "blood-brain-barrier") produced by chemical and physico-chemical agents. Acta physiol. scand. 1945, 10, 102.

36. Fisher, S. H., Troast, L., Waterhouse, A., and Shannon, J. A. The relation between chemical structure and physiological disposition of a series of substances allied to sulfanilamide. J. Pharmacol. exp. Ther. 1943, 79, 373.

37. Gyorgyi, P., and Kleinschmidt, K. Untersuchungen über die Fleischintoxikation bei Hunden mit Eckscher Fistel. Z. ges. exp. Med. 1927, 54, 1.

38. Vanamee, P., Poppell, J. W., Glicksman, A. S., Randall, H. T., and Roberts, K. E. Respiratory alkalosis in hepatic coma. Arch. intern. Med. 1956, 97, 762.

39. Robin, E. D., Whaley, R. D., Crump, C. H., and Travis, D. M. The nature of the respiratory acidosis of sleep and of the respiratory alkalosis of hepatic coma (abstract). J. clin. Invest. 1957, 36, 924. 